Stanisław MŁYNARSKI ${ }^{1}$, Robert PILCH ${ }^{2}$, Maksymilian SMOLNIK ${ }^{2}$, Jan SZYBKA ${ }^{2}$, Grzegorz WIĄZANIA ${ }^{2}$

${ }^{1}$ Cracow University of Technology (Politechnika Krakowska)

${ }^{2}$ AGH University of Science and Technology (Akademia Górniczo-Hutnicza)

\title{
A SIMULATION MODEL FOR REGENERATED OBJECTS WITH MULTIPARAMETER EVALUATION OF TECHNICAL CONDITION RELIABILITY ESTIMATION
}

\author{
Model symulacyjny szacowania niezawodności \\ regenerowanych obiektów $z$ wieloparametrową \\ oceną stanu technicznego
}

\begin{abstract}
The paper presents the developed simulation model allowing one to estimate the reliability of objects whose technical condition is described by a set of geometrical features. Their values change during operation because of the wearing processes of the part under consideration. The operational availability (or unavailability) of a technical object is determined by the evaluation conducted using a set of criteria referring to its analysed features. In addition, the proposed model enables one to take into account the regeneration of such objects.
\end{abstract}

Keywords: reliability, wear, computer simulation, renewal

Streszczenie: W artykule zaprezentowano opracowany model symulacyjny przeznaczony do wyznaczania niezawodności obiektów, których stan techniczny charakteryzowany jest za pośrednictwem zespolu cech geometrycznych. Ich wartości ulegaja zmianom $w$ czasie eksploatacji, na skutek postępującego zużycia. O zdatności (albo niezdatności) obiektu technicznego decyduje ocena przeprowadzana z wykorzystaniem zestawu kryteriów odnoszacych się do jego analizowanych cech. Zbudowany model umożliwia ponadto uwzględnienie regeneracji takich obiektów.

Słowa kluczowe: niezawodność, zużycie, symulacja komputerowa, odnowa 


\section{Introduction}

Simulation methods, despite their disadvantages, are used in research of various systems: physical, military, social, energetic, political and economic. The complexity of these systems, and in particular the difficulties in obtaining solutions using analytical methods, necessitate the use of simulation methods. Such a wide range of applications results mainly from the possibility of using a number of types of simulations and their adaptation to various models of the reality being examined $[2,7,8,14]$.

Due to its advantages, digital simulation is also used in reliability analyses. The use of simulations for estimating the reliability of renewable systems with structural redundancy in the form of additional elements is presented in [5]. The influence of the number of redundant elements on the reliability of the entire system was demonstrated in cases when the system consists of a large number of basic elements. The study [9] presents the use of simulation to estimate the reliability of a complex technical system with a structure of type k out of $n$, in which the elements are renewed after failure and can be renewed preventively if they have been working without failure during a fixed period of time. The introduced changes of time till preventive renewal of the elements cause changes in the reliability of the system in the considered period. The results obtained in simulation experiments allow to determine such time till preventive renewal of elements, so that in the analysed time the system can be characterised by the assumed level of reliability. Stochastic simulation is also used in estimating the reliability of systems having network structures in which there is a problem of determining the reliability structure (cf. [6]). The study [10] presents the possibility of estimation of reliability of modelled networks using simulation, graph theory and the factorization algorithm. Obtained results can be used in the selection of network structures at the stage of their design, modernisation and extending.

The paper presents a developed simulation calculation model for estimating the reliability of regenerated objects with a multi-parameter assessment of their technical condition. The correct functioning of this model has been verified on the example of an object, which is the wheel of a railway vehicle.

\section{Multistate regenerated technical objects}

It has been assumed that the reliability state of a technical object, which may be, for example, an analysed in the article rail vehicle wheel, depends on its technical condition, and the object itself may be available (when it may work 
properly) or unavailable (otherwise). At the same time, the technical condition of the object described with $n$ significant features due to its proper operation is characterised by a feature vector (cf. [12]):

$$
X(t, w)=\left[x_{1, w}(t), x_{2, w}(t), \ldots, x_{n, w}(t)\right]
$$

where:

$x_{i, w}(t)$ - value of feature $i$ of the object operating in the time period $\langle 0, t)$ in conditions $w$,

$t-$ moment in the history of operation and maintenance process in which the technical condition of the object is described,

$n$ - number of considered features of the object,

$w \quad-$ operation and maintenance conditions in the time period $\langle 0, t)$.

Due to the conditions of the operation and maintenance practice, it is important to determine the relationship between the technical condition of the object and its reliability state. It was assumed that the whole object remains available if and only if the value of each of its distinguished features does not exceed the accepted (required) limit values $[12,13]$ :

- for one feature with the value of $c(t)$ at time $t$ :

$$
\mathrm{OT}_{\mathrm{zd}}(t) \Leftrightarrow\left[\left(c(t) \geq c_{\min }\right) \wedge\left(c(t) \leq c_{\max }\right)\right],
$$

- for $n$ features with the values $c_{i}(t)$ at times $t, i=1,2, \ldots, n$ :

$$
\mathrm{OT}_{\mathrm{zd}}(t) \Leftrightarrow \bigwedge_{i}\left(c_{\min } \leq c_{i}(t) \leq c_{\max }\right) .
$$

Therefore, it may be said that in the operation and maintenance process, the examined technical object may become unavailable at time $t\left(\mathrm{OT}_{\mathrm{nzd}}(t)\right)$ due to exceeding by the value of at least one of its considered features of the appropriate limit value (minimum or maximum). This is correct on the assumption that as a result of the course of the object's operation and maintenance process, the values of its features may change in a continuous or stepwise manner. This is a typical undesirable consequence of the progressive degradation processes (e.g. wear, fatigue, corrosion, erosion, aging) accompanying its use.

With such a description of the technical condition of a technical object and the formulation of the condition of its availability, the desired changes in the technical condition of the object caused by its regeneration can be interpreted as changes in the value of its certain features. They occur by increasing the absolute value of the 
difference between the value of $i$ feature and the relevant limit value and lead to extending the durability (cf. $[12,13])$ :

$$
\left[\left|c_{i \mathrm{r}}(t)-c_{i \min }\right|>\left|c_{i \mathrm{z}}(t)-c_{i \min }\right|\right]
$$

or

$$
\left[\left|c_{i \mathrm{r}}(t)-c_{i \max }\right|>\left|c_{i \mathrm{z}}(t)-c_{i \max }\right|\right]
$$

where:

$r, z$ - relate respectively to the values of the features after and before the regeneration of the object operating in the time period $\langle 0, t)$.

The proper description (one out of the two mentioned cases) may be applied depending on whether the value of its $i$ feature decreases or increases as a result of using the object.

This problem was solved in the article using the developed simulation program.

\section{Simulation model for reliability estimation}

The reliability estimations obtained with the use of computer simulation allow to support decision-making processes in the range of rational choices regarding: system's structure, type of redundancies used, maintenance system, number of redundant objects or strategies of inspections and preventive renewal of objects used. They are already made at the design stage of the technical system. These issues were analysed and presented in many publications $[1,4,5,15]$.

This article presents a simulation method for evaluation of the reliability of objects characterised by the fact that their wear process is proceeding in several different ways and each of them causes changes in the value of specific features. Each of the features has an accepted limit value, the achievement of which is tantamount to the failure of the object due to this feature. In accordance with the activities applied in the operational practice of these objects, it has been assumed that it is possible to regenerate the object several times during its operation. Conducted regeneration process causes a step change in the value of specific features - to the initial state (like new), at the expense of increasing the degree of wear of the object characterised by another feature, which determines the possibility of further regeneration of the whole object. The values of this feature are also subject to changes due to wear during the operation, regardless of 
regeneration. Therefore, the technical condition of the object after regeneration is not equivalent to the technical condition of the object after complete renewal (like new), although it is assumed that the values of some of its features correspond to the situation of the object fully renewed. The overall reliability structure of such an object is shown in fig. 1 .

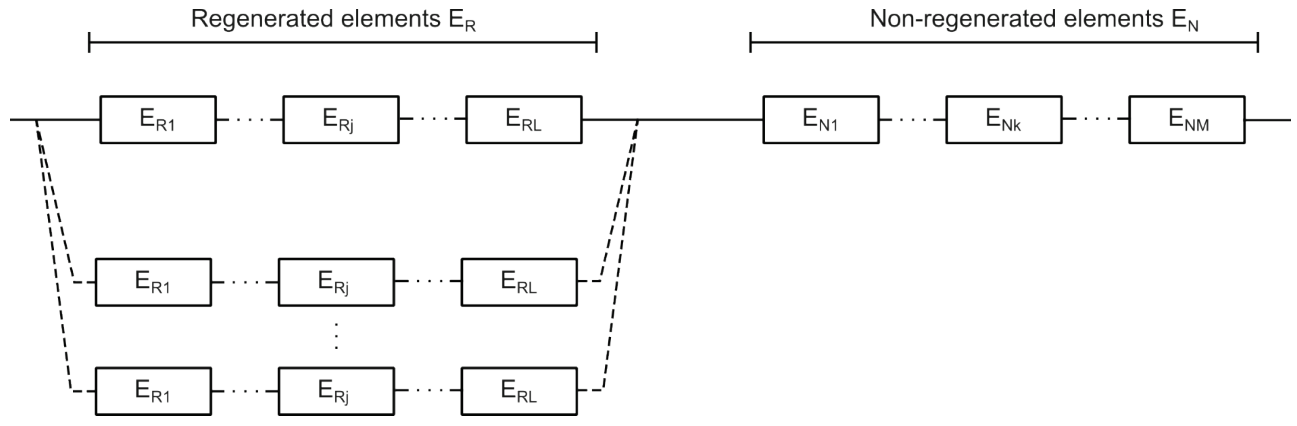

Fig. 1. Overall reliability structure of analysed object (reflecting the dependence of object's reliability state on its selected features)

On the basis of information about the real operation process of such objects, a simulation model was developed that reflects the random process of the object's wear in view of each of the distinguished features and includes carrying out the regeneration of the object until its total durability expires.

The iteration algorithm is shown in fig. 2.

The input to the algorithm is: reliability structure of a system, specified number of regenerations, reliability functions of system elements, time horizon and time step.

To implement the task, stochastic simulation with a constant time step has been used, in which random moments (in accordance with the probability distribution) of the object's failures are determined due to exceeding the value of a given feature. If the failure is the result of exceeding the value of the factor that determines conducting regeneration process and their number has not exceeded the limit, regeneration restores the object's availability and initial state of the relevant features, and the iteration of the simulation continues. If the failure is the result of exceeding the value of the feature not decisive for regeneration, then the object becomes unavailable and the iteration is interrupted. A single iteration of the simulation ends with the object's failure or is successful if the object does not become unavailable before the time horizon expires.

The simulation experiment includes the implementation of many iterations. In practice, their number is a minimum of 10,000 . 
Conducting experiments according to the developed simulation allows estimating the reliability of the considered objects in the assumed time horizon of operation and maintenance, which can be used in planning the times of their inspections, exchanges and the necessary number of spare parts.

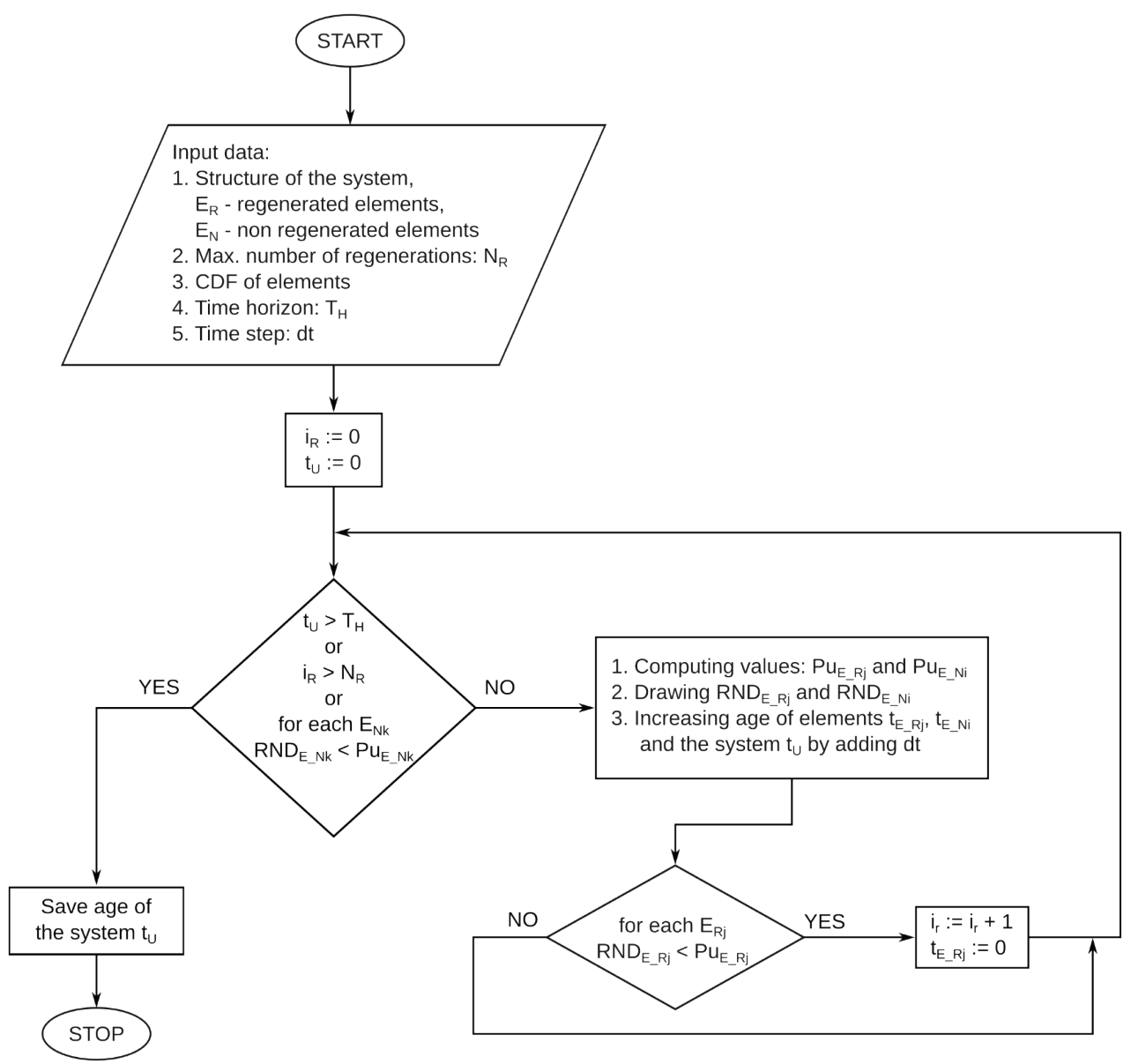

Fig. 2. Algorithm of a single iteration of the developed simulation procedure

\section{Physical aspects of rail vehicles wheels wear}

The estimation of reliability indexes of objects whose parts are subject to degradation at different paces with each other is of great importance in the analysis of reliability and durability of real technical objects. A good example of this type 
of objects are wheels of railway vehicles, on the example of which the analysed problem is presented below.

The safety of rail vehicle operation is primarily dependent on the availability of wheelsets. The intensity of wear and the failure rate of sudden failures resulting from random factors damaging vehicle wheels is of paramount importance in the use of rolling stock $[3,9]$.

Ensuring the safety of the operation of rail vehicles depends on the preservation of a wheel profile set out by the standard. The wheel profile is a specially shaped curvature of the outer surface of the wheel rim, which consists of two parts: a tread surface, wheel flange. Meeting the requirements of the standard is accomplished by maintaining specific boundary dimensions of both the tread surface and the wheel flange. A view of an exemplary wheel profile [16] is shown in fig. 3 [17].

Wheels of rail vehicle wheelsets still constitute a significant maintenance problem and in use they may reach limit values of wear and are subjected to damage and require frequent profile renewal. Analysis of the characteristics provides data on the behavior of these elements in the conditions of their operation.

During the operation of vehicles there is wear of wheelsets on the wheel tread, and in particular the area in the region of the flange constituting the transition zone to the traed. The observation of the operation and maintenance process shows that the vehicles in the service cycle, in accordance with the maintenance system documentation, during the mileage of 500,000 km undergo two profile regeneration treatments (so-called full reprofiling) with parameters defined for the S1002 profile according to the PN-EN 13715 standard [16].

The comparison of factors affecting the durability of wheelsets in the aspect of wheel flange wear and wheel wear on the running thread in the case under consideration indicates that wear of the flange ('undercut' or sharp flange) is a decisive factor in the need to reprofile wheels. The running thread wear is not a factor determining the durability of a wheelset, despite the fact that the limit size of the running thread determines the withdrawal of the wheelset from operation. The dominant influence on reducing the value of the 'rim diameter' feature is the fact that the edge is reprofiled.

The analysed results of operational tests of wear showed that 'under-cutting' of the wheel flange determines the need for regeneration of the majority of wheelsets. The renewal of the tread profile and dimensions of the flange depends on the dimensions of the tread and, in order to maintain the required dimensions of the wheels - of the wheelset and the dimensions of all wheels of the vehicle trolley determines the durability of the wheelsets. Taking into account the results of the tests, it is also important to accurately plan the renewal operations of the rail vehicle 
trolleys and forecast the durability of the wheel rims. The obtained results of the simulation of durability and reliability of rail vehicle wheels with the proposed method can be used to optimise the maintenance process and improve the economics of railway vehicle operation and other technical objects with multiparameter evaluation of their technical condition.

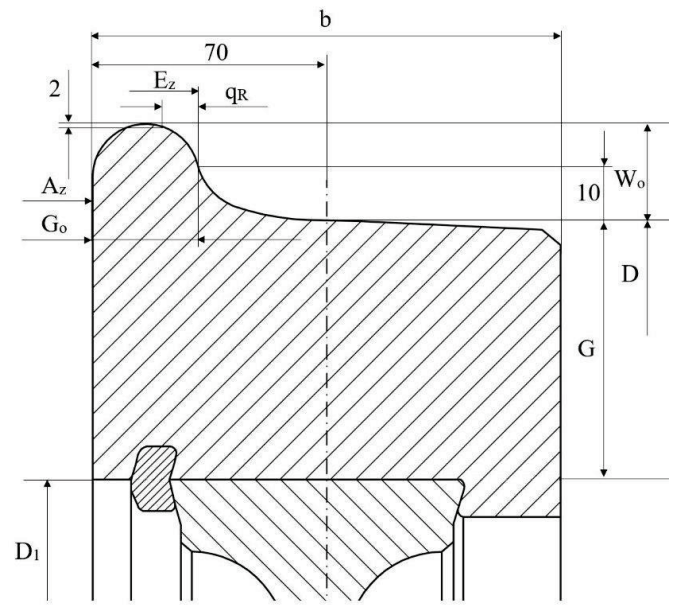

Fig. 3. A view of an exemplary wheel profile [17] - marking of measurable features of the rolling profile of the wheel: $\mathrm{G}$ - tyre thickness, $\mathrm{G}_{\mathrm{O}}$ - flange thickness, $\mathrm{W}_{\mathrm{O}}$ - flange height, $\mathrm{q}_{\mathrm{R}}$ - flange slope, $\mathrm{b}$ - width of the tyre or the monoblock wheel rim, $\mathrm{Az}-$ distance between tyre back surfaces or rims of monoblock wheels in the wheelsets without load, $\mathrm{D}$ - rim diameter, $\mathrm{D}_{1}-$ wheel centre diameter, $\mathrm{E}_{\mathrm{z}}$ - distance between flange profiles

\section{Exemplary calculation}

In the analysed case, based on the data collected during the operation of selected rail vehicles, the distributions of the probability of mileage to reaching the limit state were determined. The object under consideration is the wheel of a rail vehicle. Selected features describing the wear (and also the technical condition) of the object are: wheel diameter (D), flange thickness (GO) and wheel profile outline $(\mathrm{P})$. The obtained probability density functions $(\mathrm{f}(\mathrm{s}))$ of mileage to reaching the limit state for each of the analysed features are shown in fig. 4.

The diameter and outline of the profile are described using Weibull distribution with a density function in the form of: 


$$
\mathrm{f}(s)=v\left(\frac{1}{\beta}\right)^{v} s^{v-1} \exp \left(-\left(\frac{s}{\beta}\right)^{v}\right)
$$

and the outline of the profile using normal distribution. The values of the distribution parameters are given in tab. 1 .

Table 1

The values of the distribution parameters

\begin{tabular}{|c|c|c|c|}
\hline Wheel feature & Profile outline $\mathrm{P}$ & Flange thickness Go & Wheel diameter $\mathrm{D}$ \\
\hline $\begin{array}{l}\text { Distribution and } \\
\text { its parameters }\end{array}$ & $\begin{array}{l}\text { normal: } \\
\mathrm{m}=215000 \mathrm{~km} \\
\sigma=60000 \mathrm{~km}\end{array}$ & $\begin{array}{l}\text { Weibull: } \\
v=5 \\
\beta=158000 \mathrm{~km}\end{array}$ & $\begin{array}{l}\text { Weibull: } \\
v=3,4 \\
\beta=429000 \mathrm{~km}\end{array}$ \\
\hline
\end{tabular}

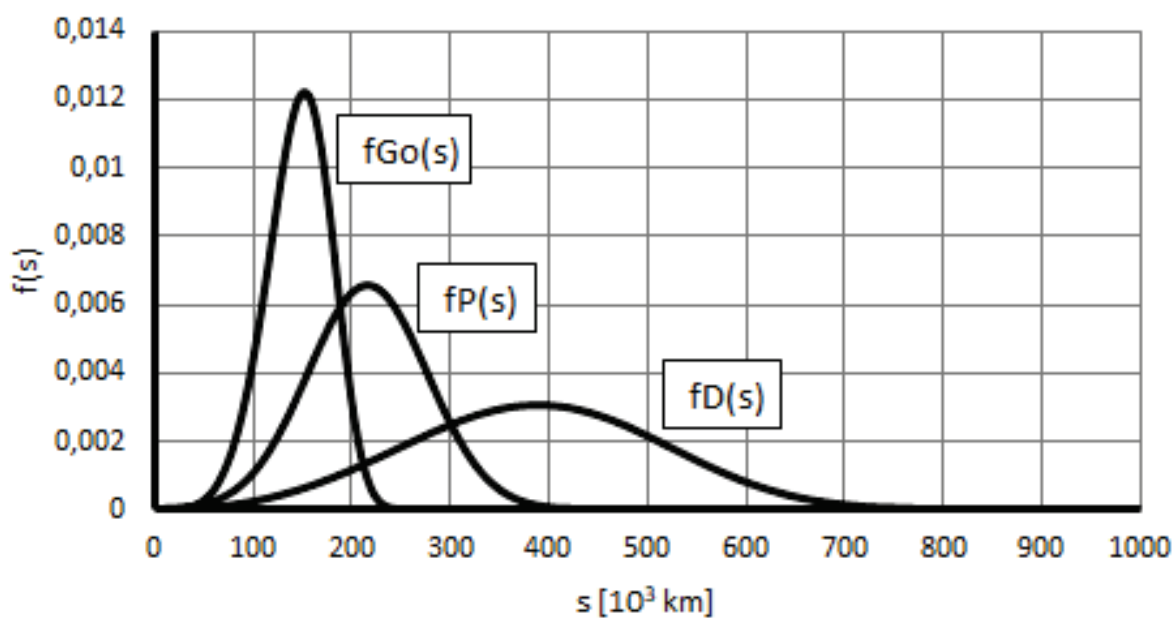

Fig. 4. Graphs of probability density functions ( $\mathrm{f}(\mathrm{s})$ ) of mileage to reaching the limit state: $\mathrm{fD}(\mathrm{s})$ - wheel diameter, $\mathrm{fP}(\mathrm{s})$ - profile outline, $\mathrm{fG}_{\mathrm{O}}(\mathrm{s})$ - flange thickness

The wheel reliability structure, determined by a set of listed features, is shown in fig. 5 . 


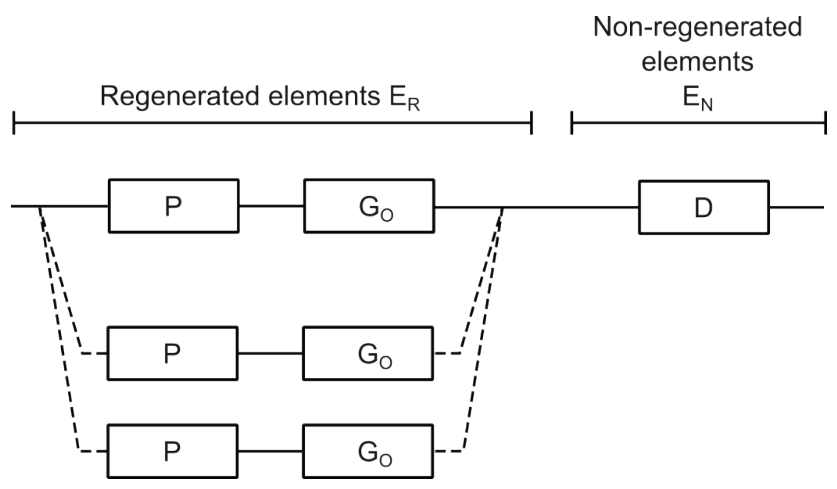

Fig. 5. Considered reliability structure of a rail vehicle wheel

On the basis of the adopted model of the system (fig. 5) and the algorithm of the simulation procedure (fig. 2) a computer program was developed to simulate system's operation. The simulation parameters were:

- time step dt equal to $5000 \mathrm{~km}$,

- time horizon TH equal to $600000 \mathrm{~km}$,

- number of iterations $\mathrm{n}$ equal to 10000 .

The reliability estimations obtained from the conducted simulations are shown in fig. 6 .

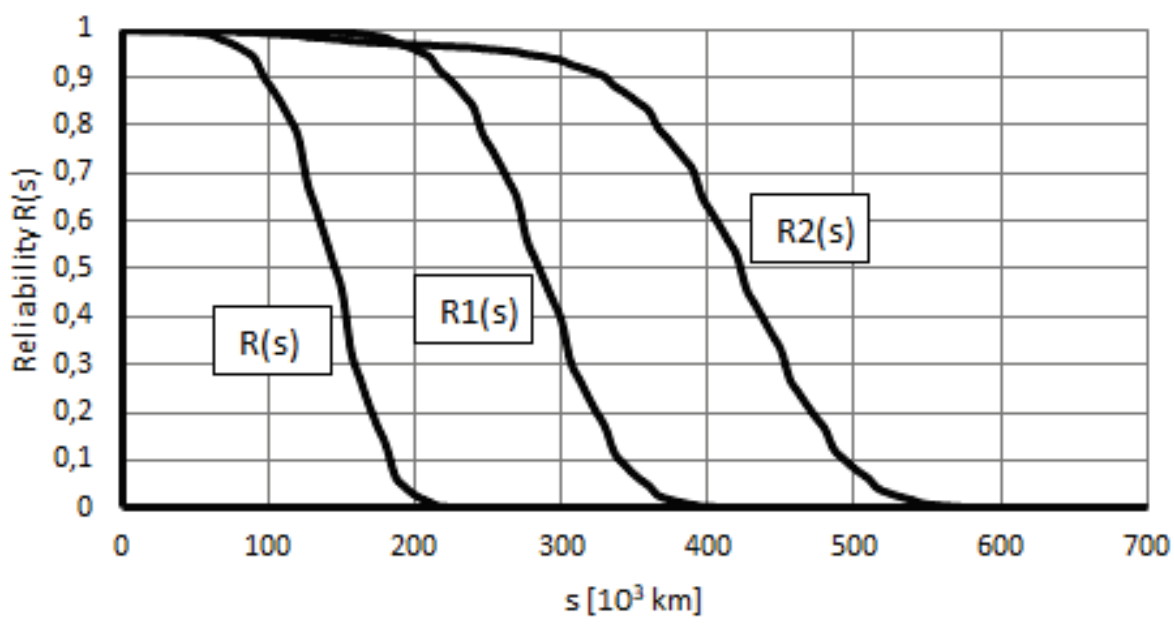

Fig. 6. Obtained courses of reliability function of a rail vehicle wheel: R(s) - reliability of the wheel when regeneration is not carried out, R1(s) with one and R2(s) with two regenerations 
The analysis of the obtained mileage indicates a significant effect of regeneration on the reliability of operation and durability of the considered vehicle wheel. Culmination of failures by mileage of about $150000 \mathrm{~km}$ (fig. 4) now does not directly cause a significant change in the reliability of the entire object after it reaches this mileage $(s)$. When only one regeneration is performed, the mileage is almost doubled to reach a similar level of reliability (R2 $(s)$ ), and with double regeneration almost three times $(\mathrm{R} 3(s))$. However, a non-regenerated feature, which is the diameter of the wheel, has a significant impact on reliability.

\section{Conclusions}

In the field of analysis and estimation of reliability and readiness of technical systems, the most common tool applied is a stochastic computer simulation, an example of which is presented in the article. This simulation makes it possible to obtain reliability estimations in much shorter time than would be necessary to evaluate reliability on the basis of observations of real systems and with significantly lower costs. Due to the possibility of repeating the experiment in unchanged conditions, it allows to obtain large numbers of parameter values (which can be referred to as values of considered features) required to evaluation reliability, and difficult to observe in practice, especially when the analysed systems are unique or present in a small number. In addition, the values of features that are important in the evaluation of reliability, and which are random variables of specific probability distributions (such as working times till failure, duration of renewal, etc.) in a computer simulation experiment may easily be obtained by using random number generators.

The simulation method presented in the paper may be successfully used to predict the durability of rail vehicle wheels. In the developed simulation model, the influence of regeneration activities (wheel reprofilation) on extending the working time of wheelsets of rail vehicles is evident. It is also possible to use it for planning and synchronising regenerative activities of individual wheels functioning in wheel sets.

This work was financed by AGH University of Science and Technology, Faculty of Mechanical Engineering and Robotics, research program No. 11.11.130.174. 


\section{References}

1. Faulin J., Juan Perez A.A., Martorell Alsina S.S., Ramirez-Marquez J.E. (eds.): Simulation Methods for Reliability and Availability of Complex Systems. Springer. London 2012.

2. Fishman G.S.: Symulacja komputerowa. Pojęcia i metody. PWE. Warszawa 1981.

3. Młynarski S., Piec P.: In-service analysis of tram wheel set life. Problemy Transportu - Transport Problems, Vol. 7 (2), 2012.

4. Młynarski S., Pilch R., Smolnik M., Szybka J., Wiązania G.: A Method for rapid evaluation of k-out-of-n systems reliability. Eksploatacja i Niezawodność Maintenance and Reliability, Vol. 21 (1), 2019

5. Młynarski S., Pilch R., Smolnik M., Szybka J., Wiązania G.: Formation of koon Systems Reliability Estimated with Analytical and Simulation Calculation Methods. Journal of KONBiN, No. 42, 2017, DOI 10.1515/jok-2017-0028.

6. Młynarski S., Pilch R., Smolnik M., Szybka J., Wiązania G.: Methodology of network systems reliability assessment on the example of urban transport. Eksploatacja i Niezawodnosc - Maintenance and Reliability, Vol. 20 (2), 2018.

7. Naylor T.H.: Modelowanie cyfrowe systemów ekonomicznych. PWN. Warszawa 1975.

8. Perkowski P.: Technika symulacji cyfrowej. WNT. Warszawa 1980.

9. Piec P.: Badania eksploatacyjne elementów i zespołów pojazdów szynowych. Wyd. Politechniki Krakowskiej. Kraków 2004.

10. Pilch R.: A method for obtaining the required system reliability level by applying preventive maintenance. Simulation: Transactions of the Society for Modeling and Simulation International, Vol. 91 (7), 2015.

11. Pilch R.: Reliability evaluation of networks with imperfect and repairable links and nodes. Eksploatacja i Niezawodnosc - Maintenance and Reliability, Vol. 19 (1), 2017

12. Sowa A.: Ocena stanu technicznego pojazdów szynowych na podstawie cech zdeterminowanych. Politechnika Krakowska. Kraków. 2013.

13. Sowa A.: Formal models of generating checkup sets for the technical condition evaluation of compound objects. Eksploatacja i Niezawodność - Maintenance and Reliability, Vol. 16 (1), 2014.

14. Tyszer J.: Symulacja cyfrowa. WNT. Warszawa 1990.

15. Wiązania G., Smolnik M., Pilch R.: An estimation of koon systems availability using a simulation method. Journal of Machine Construction and Maintenance, No. 4, 2017.

16. PN-EN 13715+A1: 2011: Kolejnictwo - Zestawy kołowe i wózki - Koła - Zewnętrzne zarysy wieńców kół.

17. Instrukcja pomiarów i oceny technicznej zestawów kołowych pojazdów trakcyjnych Bt-11. PKP Intercity, 2010. 


\section{MODEL SYMULACYJNY SZACOWANIA NIEZAWODNOŚCI REGENEROWANYCH OBIEKTÓW \\ Z WIELOPARAMETROWĄ OCENĄ STANU TECHNICZNEGO}

\section{Wprowadzenie}

Metody symulacyjne, mimo wad, znajdują zastosowanie w badaniach różnych systemów: fizycznych, wojskowych, społecznych, energetycznych, politycznych, a także ekonomicznych. Złożoność tych systemów, a w szczególności trudności w uzyskaniu poszukiwanych rozwiązań w drodze analitycznej, powoduje konieczność stosowania metod symulacyjnych. Tak szeroki obszar zastosowań wynika przede wszystkim z możliwości wykorzystywania wielu typów symulacji i ich adaptacji do różnych modeli badanej rzeczywistości $[2,7,8,14]$.

Ze względu na swoje zalety symulacja cyfrowa jest również wykorzystywana w analizach niezawodności. Zastosowanie symulacji do szacowania niezawodności odnawialnych układów posiadających nadmiar strukturalny $\mathrm{w}$ postaci dodatkowych elementów przedstawiono w [5]. Wykazano wpływ liczby elementów rezerwowych na niezawodność całego układu, w przypadkach gdy układ składa się z dużej liczby elementów podstawowych. W opracowaniu [9] zaprezentowano wykorzystanie symulacji do wyznaczania niezawodności złożonego układu technicznego o strukturze typu $\mathrm{k}$ z n, w którym elementy są odnawiane po uszkodzeniu oraz mogą być odnawiane prewencyjnie, jeśli bezawaryjnie przepracowały ustalony czas. Wprowadzane zmiany okresów odnowy prewencyjnej elementów powodują zmiany niezawodności układu w przyjętym okresie. Uzyskane w eksperymentach symulacyjnych wyniki umożliwiają wyznaczenie takich okresów odnów prewencyjnych elementów, aby w analizowanym czasie układ utrzymał założony poziom niezawodności. Symulacja stochastyczna jest również wykorzystywana w szacowaniu niezawodności układów posiadających struktury sieciowe, w których występuje problem określenia struktury niezawodnościowej (por. [6]). W opracowaniu [10] przedstawiono możliwość symulacyjnego szacowania niezawodności sieci modelowanych $\mathrm{z}$ wykorzystaniem teorii grafów i algorytmu faktoryzacji. 
Uzyskiwane wyniki mogą być wykorzystane w doborze struktur sieci na etapie ich projektowania, modernizacji i rozbudowy.

W artykule pokazano opracowany symulacyjny model obliczeniowy przeznaczony do szacowania niezawodności regenerowanych obiektów z wieloparametrową oceną ich stanu technicznego. Poprawność funkcjonowania tego modelu zweryfikowano na przykładzie obiektu, jakim jest koło pojazdu szynowego.

\section{Wielostanowe regenerowane obiekty techniczne}

Przyjęto założenie, że stan niezawodnościowy obiektu technicznego, którym może być np. analizowane w artykule koło pojazdu szynowego, jest zależny od jego stanu technicznego, a sam obiekt może być zdatny (gdy może pracować poprawnie) albo niezdatny (w przeciwnym przypadku). Jednocześnie, stan techniczny obiektu opisywanego $n$ cechami istotnymi z uwagi na jego prawidłową pracę, charakteryzuje wektor cech (por. [12]):

$$
X(t, w)=\left[x_{1, w}(t), x_{2, w}(t), \ldots, x_{n, w}(t)\right],
$$

gdzie:

$x_{i, w}(t)$ - wartość $i$-tej cechy obiektu eksploatowanego w czasie $\langle 0, t)$ w warun$\operatorname{kach} w$,

$t \quad$ - chwila w historii eksploatacji, w której opisywany jest stan techniczny obiektu,

$n$ - liczba rozpatrywanych cech obiektu,

$w \quad-$ warunki eksploatacji obiektu w czasie $\langle 0, t)$.

Ze względu na uwarunkowania praktyki eksploatacyjnej, istotne jest zatem określenie zależności pomiędzy stanem technicznym obiektu i jego stanem niezawodnościowym. Założono, że cały obiekt pozostaje zdatny wtedy i tylko wtedy, gdy wartość każdej z jego wyróżnianych cech nie przekracza przyjętych (wymaganych) granicznych wartości $[12,13]$ :

- dla jednej cechy o wartości $c(t) \mathrm{w}$ chwili $t$ :

$$
\mathrm{OT}_{\mathrm{zd}}(t) \Leftrightarrow\left[\left(c(t) \geq c_{\min }\right) \wedge\left(c(t) \leq c_{\max }\right)\right],
$$

- dla $n$ cech o wartościach $c_{i}(t) \mathrm{w}$ chwili $t, i=1,2, \ldots, n$ : 


$$
\mathrm{OT}_{\mathrm{zd}}(t) \Leftrightarrow \bigwedge_{i}\left(c_{\min } \leq c_{i}(t) \leq c_{\max }\right) .
$$

Tym samym można powiedzieć, że w procesie eksploatacji badany obiekt techniczny może stać się niezdatny w chwili $t\left(\mathrm{OT}_{\mathrm{nzd}}(t)\right)$ z powodu przekroczenia przez wartość choćby jednej, dowolnej z rozpatrywanych jego cech odpowiedniej dla niej wartości granicznej (minimalnej albo maksymalnej). Jest to słuszne przy założeniu, że na skutek przebiegu procesu eksploatacji obiektu, wartości jego cech mogą zmieniać się w sposób ciagły lub skokowy. Jest to typowym niepożądanym następstwem postępujących procesów jego degradacji (np. zużycia, zmęczenia, korozji, erozji, starzenia), towarzyszących jego wykorzystywaniu.

Przy tak dokonanym opisie stanu technicznego obiektu technicznego oraz sformułowaniu warunku jego zdatności, pożądane zmiany stanu technicznego obiektu spowodowane jego regeneracją mogą być interpretowane jako zmiany wartości jego pewnych cech. Zachodzą one, zwiększając wartość bezwzględną różnicy wartości $i$-tej cechy i odpowiedniej wartości granicznej oraz prowadzą do wydłużenia czasu eksploatacji (por. $[12,13])$ :

$$
\left[\left|c_{i \mathrm{r}}(t)-c_{i \min }\right|>\left|c_{i \mathrm{z}}(t)-c_{i \min }\right|\right]
$$

albo

$$
\left[\left|c_{i \mathrm{r}}(t)-c_{i \max }\right|>\left|c_{i \mathrm{z}}(t)-c_{i \max }\right|\right]
$$

gdzie:

$r, z$ - dotyczą odpowiednio wartości cech po i przed regeneracją obiektu eksploatowanego w czasie $\langle 0, t)$.

Właściwy opis spośród dwóch wymienionych przypadków znajduje zastosowanie zależnie od tego, czy na skutek wykorzystywania obiektu wartość jego $i$-tej cechy maleje, czy wzrasta.

Problem ten postarano się rozwiązać w artykule, stosując autorski program symulacyjny.

\section{Symulacyjny model szacowania niezawodności}

Oszacowania niezawodności uzyskiwane $\mathrm{z}$ zastosowaniem symulacji komputerowej pozwalają wspomagać procesy decyzyjne w zakresie racjonalnych wyborów dotyczących: struktury układu, rodzaju stosowanych nadmiarów, systemu obsługiwania, liczby obiektów rezerwowych, czy też strategii przeglądów 
i odnów prewencyjnych obiektów. Dokonywane są one już na etapie projektowania układu technicznego. Zagadnienia te analizowano i prezentowano $\mathrm{w}$ wielu publikacjach $[1,4,5,15]$.

W niniejszym artykule przedstawiono opracowaną symulacyjną metodę oceny niezawodności obiektów charakteryzujących się tym, że ich zużycie przebiega na kilka różnych sposobów i każdy z nich powoduje zmiany wartości określonych cech. Każda z cech posiada przyjętą wartość graniczną, której osiagnięcie jest równoznaczne $\mathrm{z}$ uszkodzeniem obiektu ze względu na tę cechę. Zgodnie z działaniami stosowanymi w praktyce eksploatacyjnej tych obiektów przyjęto, że istnieje możliwość kilkukrotnej regeneracji obiektu w okresie jego eksploatacji. Przeprowadzana regeneracja powoduje skokową zmianę wartości określonych cech - do stanu początkowego (jak nowe), kosztem zwiększenia stopnia zużycia obiektu charakteryzowanego inną cechą, która warunkuje możliwość kolejnych regeneracji całego obiektu. Wartości tej cechy ulegają również zmianom na skutek zużycia postępującego $\mathrm{w}$ trakcie eksploatacji niezależnie od wykonywanych regeneracji. Zatem stan techniczny obiektu po wykonaniu regeneracji nie jest równoważny stanowi technicznemu obiektu po całkowitej odnowie (jak nowy), mimo to przyjmuje się, że wartości pewnych jego cech odpowiadają sytuacji obiektu w pełni odnowionego. Ogólną strukturę niezawodnościową takiego obiektu pokazano na rys. 1 .

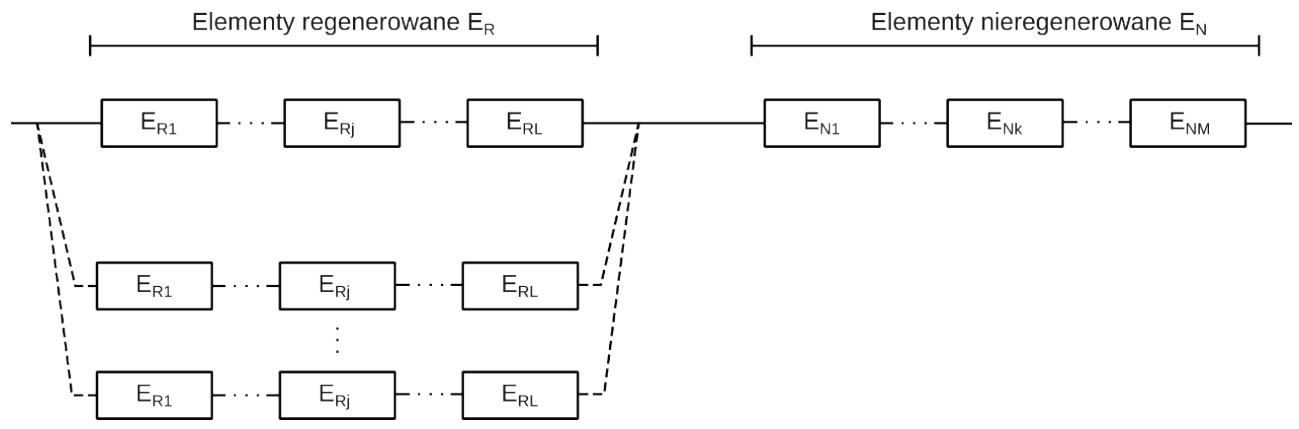

Rys. 1. Ogólna struktura niezawodnościowa analizowanego obiektu (uzależniająca stan niezawodnościowy obiektu od jego wyróżnianych cech)

$\mathrm{Na}$ podstawie informacji o rzeczywistym procesie eksploatacji takich obiektów opracowano model symulacyjny, który odzwierciedla losowy proces zużywania się obiektu ze względu na każdą z wyróżnionych cech i uwzględnia przeprowadzanie regeneracji obiektu aż do osiaggnięcia całkowitego jego zużycia.

Algorytm iteracji przedstawiono na rys. 2. 


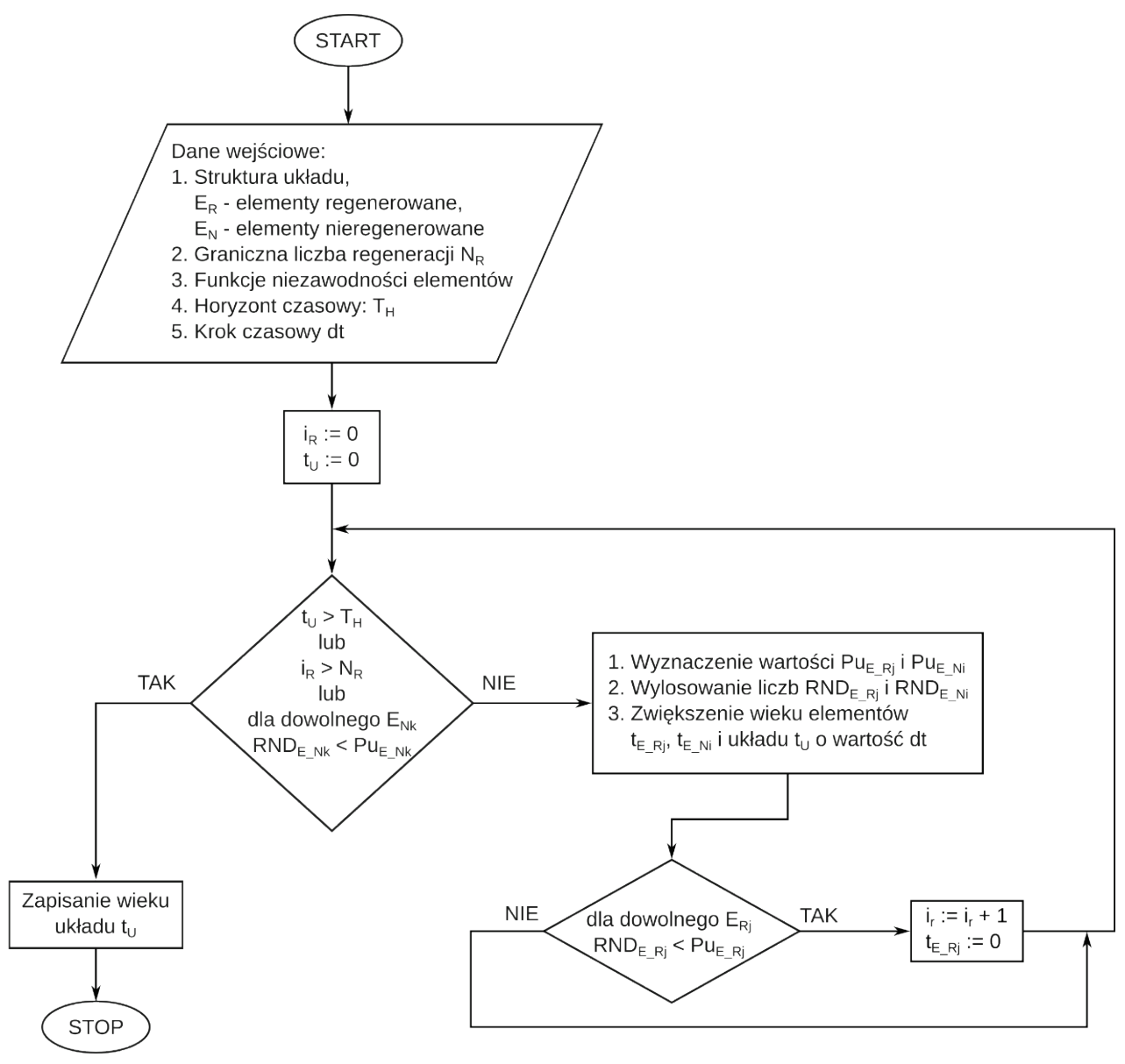

Rys. 2. Algorytm pojedynczej iteracji opracowanej procedury symulacyjnej

Danymi wejściowymi do algorytmu są: struktura niezawodnościowa układu, graniczna liczba regeneracji, funkcje niezawodności elementów układu, horyzont czasowy oraz krok czasowy.

Do realizacji zadania wykorzystano symulację stochastyczna, o stałym kroku czasowym, w której wyznaczane są losowe (zgodnie z rozkładem prawdopodobieństwa) chwile uszkodzeń obiektu ze względu na przekroczenie wartości określonej cechy. Jeśli uszkodzenie jest efektem przekroczenia wartości cechy decydującej o wykonaniu regeneracji i ich liczba nie została wyczerpana, następuje regeneracja przywracająca stan zdatności obiektu oraz stan początkowy odpowiednich cech, a iteracja symulacji trwa dalej. Jeśli uszkodzenie jest efektem przekroczenia 
wartości cechy niedecydującej o regeneracji, to następuje uszkodzenie obiektu i przerwanie iteracji. Pojedyncza iteracja symulacji kończy się uszkodzeniem obiektu lub kończy się sukcesem, jeśli przed upływem horyzontu czasowego uszkodzenie obiektu nie nastapi.

Eksperyment symulacyjny obejmuje wykonanie wielu iteracji. W praktyce ich liczba wynosi minimum 10000.

Przeprowadzenie eksperymentów według opracowanej symulacji umożliwia wyznaczenie niezawodności rozważanych obiektów w przyjętym horyzoncie czasowym eksploatacji, co może być wykorzystywane w planowaniu czasów dokonywania ich przeglądów, wymian oraz niezbędnej liczby obiektów wymiennych.

\section{Fizykalne aspekty zużycia kół pojazdów szynowych}

Duże znaczenie w analizie niezawodności i trwałości rzeczywistych obiektów technicznych ma ocena wskaźników niezawodności obiektów, których elementy podlegają degradacji w różnym tempie względem siebie. Dobrym przykładem obiektów tego rodzaju są koła pojazdów szynowych, na których przykładzie poniżej przedstawiono analizowany problem.

Bezpieczeństwo eksploatacji pojazdów szynowych przede wszystkim uzależnione jest od zdatności zestawów kołowych. Intensywność zużycia oraz intensywność uszkodzeń nagłych, wynikających z losowych czynników uszkadzających koła pojazdów, ma nadrzędne znaczenie w użytkowaniu taboru [3, 9].

Zapewnienie bezpieczeństwa eksploatacji pojazdów szynowych uzależnione jest od zachowania określonego normą profilu zarysu kół zestawów kołowych. Profil toczny koła stanowi specjalnie ukształtowana krzywizna zewnętrznej powierzchni wieńca koła, która składa się z dwóch części: powierzchni tocznej i obrzeża koła. Wymogi normy spełniane są przez zachowanie określonych wymiarów granicznych obydwu powierzchni, tj. tocznej i obrzeża koła. Widok przykładowego profilu koła [16] pokazano na rys. 3 [17].

Koła zestawów kołowych pojazdów szynowych ciągle stanowią istotny problem eksploatacyjny i w trakcie użytkowania mogą osiągnąć graniczne wartości zużycia oraz podlegać uszkodzeniom i wymagają zabiegów częstej odnowy zarysu. Analiza charakterystyk dostarcza informacji o zachowaniu się tych elementów w warunkach panujacych podczas ich pracy.

W trakcie eksploatacji pojazdów następuje zużycie zestawów kołowych na powierzchni tocznej obręczy, a w szczególności w rejonie obrzeża, w strefie przejścia w powierzchnię toczną. $Z$ obserwacji procesu eksploatacji wynika, że 
pojazdy w cyklu międzynaprawczym zgodnie z DSU (dokumentacja systemu utrzymania) w trakcie pokonywania przebiegu $500000 \mathrm{~km}$ mają wykonywane dwa zabiegi odtworzenia profilu (tzw. pełnej reprofilacji) o parametrach określonych dla profilu S1002 wg normy PN-EN 13715 [16].

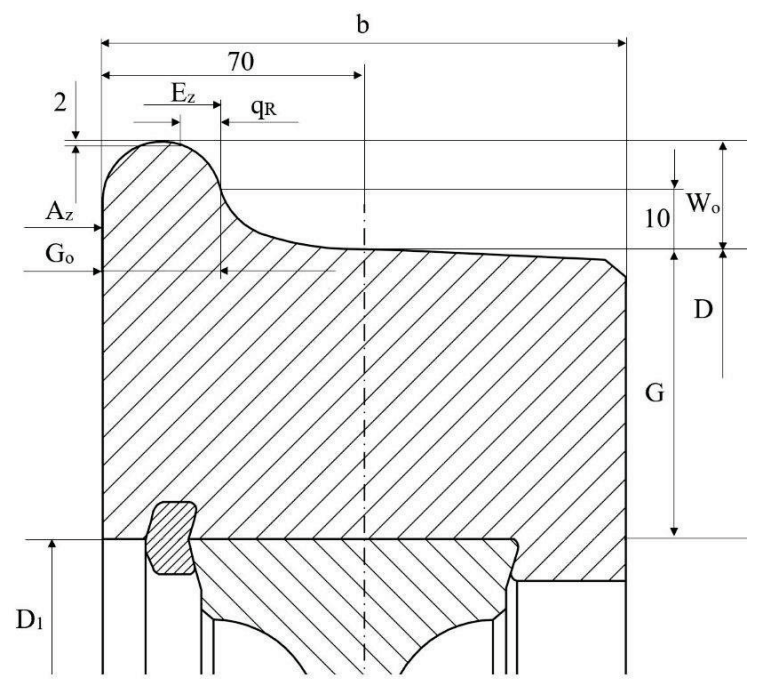

Rys. 3. Widok fragmentu koła [17] - oznaczenie cech mierzalnych profilu tocznego koła: G - grubość obręczy, Go - grubość obrzeża, $W_{O}$ - wysokość obrzeża, $\mathrm{q}_{\mathrm{R}}$ - stromość obrzeża, $\mathrm{b}$ - szerokość obręczy lub wieńca koła bezobręczowego, $\mathrm{Az}$ - odległość między wewnętrznymi powierzchniami obręczy lub wieńcami kół bezobręczowych w zestawach kołowych bez obciążenia, D - średnica okręgu tocznego, $\mathrm{D}_{1}$ - średnica koła bosego, $\mathrm{E}_{\mathrm{z}}$ - odległość między zarysami obrzeży

Z porównania czynników wpływających na trwałość zestawów kołowych pojazdu w aspekcie zużycia obrzeża koła oraz zużycia koła na kręgu tocznym w rozpatrywanym przypadku wynika, że zużycie obrzeża „podcięcie” jest czynnikiem decydującym o konieczności reprofilacji kół. Zużycie na kręgu tocznym nie jest $\mathrm{w}$ tym przypadku wielkością decydującą o trwałości zestawu kołowego, pomimo że graniczne wymiary średnicy okręgu tocznego decydują o wycofaniu zestawu kołowego z eksploatacji. Dominujący wpływ na zmniejszenie wartości cechy „średnica na okręgu tocznym” ma fakt wykonywania reprofilacji obrzeża.

Przeanalizowane wyniki badań zużycia eksploatacyjnego wykazały, że podcięcie obrzeża obręczy determinuje zużycie większości zestawów kołowych. Odnowa profilu i wymiarów obrzeża jest zależna od wymiarów powierzchni 
tocznej i ze względu na zachowanie wymaganych wymiarów kół - w zestawie kołowym oraz wymiarów wszystkich kół wózka pojazdu determinuje trwałość zestawów kołowych. Uwzględniając wyniki badań, istotna jest również możliwość dokładnego planowania zabiegów naprawczych wózków pojazdu szynowego oraz prognozowania trwałości obręczy kół. Uzyskane wyniki symulacji trwałości i niezawodności kół pojazdów szynowych proponowaną metodą mogą być wykorzystane do optymalizacji procesu obsługi oraz poprawy ekonomiki eksploatacji pojazdów szynowych oraz innych obiektów z wieloparametrową oceną stanu technicznego.

\section{Przykład obliczeniowy}

$\mathrm{W}$ analizowanym przypadku, bazując na danych zgromadzonych w czasie eksploatacji wybranych pojazdów szynowych, określono rozkłady prawdopodobieństwa przebiegu do osiagnięcia stanu granicznego. Rozpatrywanym obiektem jest koło pojazdu szynowego. Wyróżnionymi cechami opisującymi zużycie (a zarazem stan techniczny) obiektu są: średnica koła (D), grubość obrzeża $\left(\mathrm{G}_{\mathrm{O}}\right)$ oraz zarys profilu (P). Uzyskane funkcje gęstości prawdopodobieństwa przebiegu (f(s)) do osiagnięcia stanu granicznego dla każdej $\mathrm{z}$ analizowanych cech przedstawiono na rys. 4 .

Średnicę oraz zarys profilu opisuje rozkład Weibulla z funkcją gęstości w postaci:

$$
\mathrm{f}(s)=v\left(\frac{1}{\beta}\right)^{v} s^{v-1} \exp \left(-\left(\frac{s}{\beta}\right)^{v}\right)
$$

a zarys profilu rozkład normalny. Wartości parametrów rozkładów zamieszczono w tab. 1.

Tabela 1

\section{Parametry rozkładów prawdopodobieństwa}

\begin{tabular}{|c|c|c|c|}
\hline Cecha koła & Zarys profilu $\mathrm{P}$ & Grubość obrzeża Go & Średnica koła D \\
\hline $\begin{array}{l}\text { Rozkład } \\
\text { i parametry }\end{array}$ & $\begin{array}{l}\text { normalny: } \\
\mathrm{m}=215000 \mathrm{~km} \\
\sigma=60000 \mathrm{~km}\end{array}$ & $\begin{array}{l}\text { Weibulla: } \\
v=5 \\
\beta=158000 \mathrm{~km}\end{array}$ & $\begin{array}{l}\text { Weibulla: } \\
v=3,4 \\
\beta=429000 \mathrm{~km}\end{array}$ \\
\hline
\end{tabular}




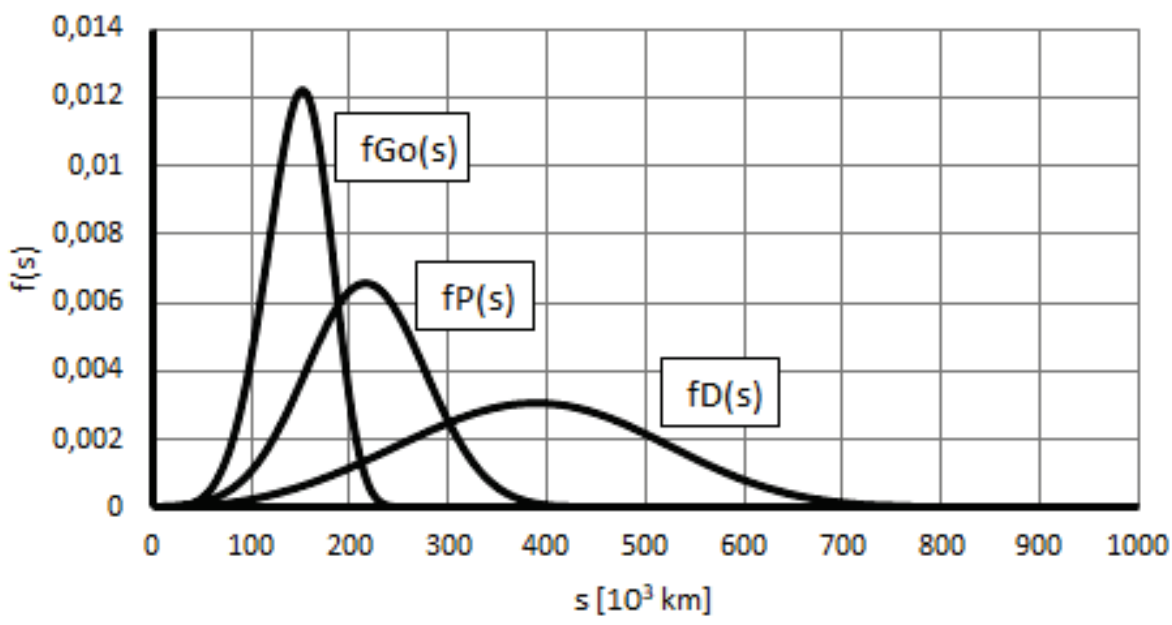

Rys. 4. Wykresy funkcji gęstości prawdopodobieństwa przebiegu do osiagnięcia stanu granicznego: $\mathrm{fD}(\mathrm{s})$ - średnica koła, $\mathrm{fP}(\mathrm{s})$ - geometria profilu, $\mathrm{fG}_{\mathrm{o}}(\mathrm{s})$ - grubość obrzeża

Strukturę niezawodnościową koła, wyznaczaną przez zespół wymienionych cech, pokazano na rys. 5 .

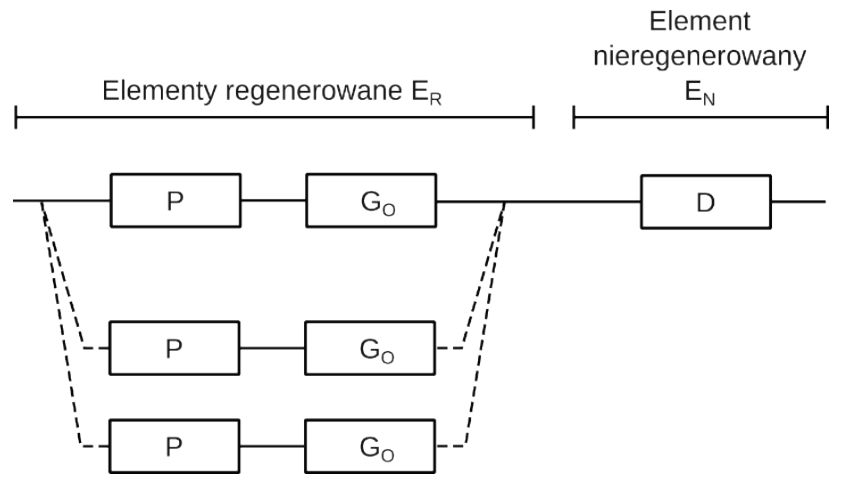

Rys. 5. Przyjęta struktura niezawodnościowa koła pojazdu szynowego

Na podstawie przyjętego modelu układu (rys. 5) oraz algorytmu procedury symulacyjnej (rys. 2) opracowano program komputerowy pozwalający na symulację jego pracy. Parametry symulacji wynosiły:

- krok czasowy $d t$ równy 5 tys. km,

- horyzont czasowy $T_{H}$ równy 600 tys. km, 
- liczba iteracji $n$ równa 10000.

Oszacowania niezawodności uzyskane na podstawie przeprowadzonych symulacji przedstawiono na rys. 6 .

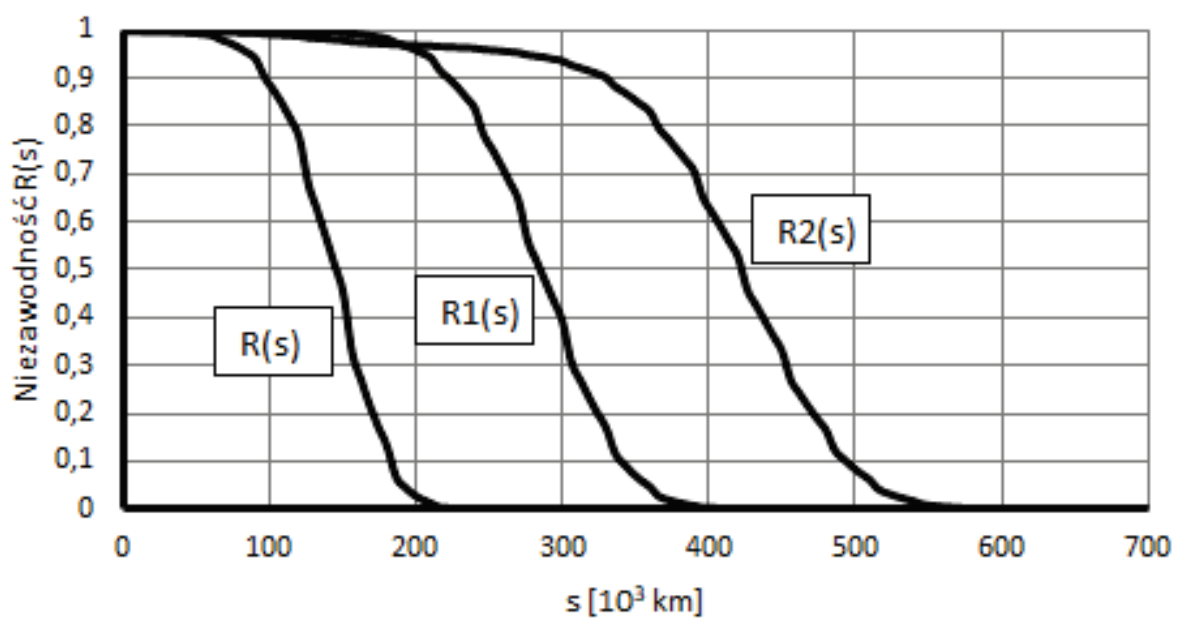

Rys. 6. Uzyskane przebiegi funkcji niezawodności koła pojazdu szynowego: R(s) niezawodność koła, gdy nie jest wykonywana regeneracja, R1(s) z jedną, a R2(s) $\mathrm{z}$ dwiema regeneracjami

Analiza uzyskanego przebiegu wskazuje na znaczący wpływ regeneracji na niezawodność funkcjonowania i trwałość rozpatrywanego koła pojazdu szynowego. Kulminacja uszkodzeń przypadająca na przebieg ok. 150 tys. km (rys. 4) nie przekłada się teraz bezpośrednio na istotną zmianę niezawodności całego obiektu po osiagnięciu przez niego tej wartości przebiegu (s). Przy wykonywaniu tylko jednej regeneracji obserwuje się prawie dwukrotny wzrost przebiegu do osiagnięcia zbliżonego poziomu niezawodności (R2(s)), a przy dwukrotnej regeneracji prawie trzykrotny (R3(s)). Istotny wpływ na niezawodność wykazuje natomiast cecha nieregenerowana, którą jest średnica koła.

\section{Podsumowanie}

W zakresie analiz i szacowania niezawodności oraz gotowości układów technicznych najczęściej wykorzystywana jest stochastyczna symulacja komputerowa, której przykład zastosowania przedstawiono w artykule. Symulacja 
ta umożliwia uzyskanie oszacowań niezawodności w czasie znacznie krótszym niż byłby konieczny do oceny niezawodności na podstawie obserwacji układów rzeczywistych i przy zdecydowanie niższych kosztach. Dzięki możliwości wielokrotnego powtarzania eksperymentu w niezmienionych warunkach, pozwala uzyskiwać duże liczności wartości parametrów (które mogą być określane jako wartości rozpatrywanych cech) wymaganych do oceny niezawodności, a trudnych do zaobserwowania w praktyce, szczególnie gdy analizowane układy eksploatowane są jako unikatowe lub występują w niewielkiej liczbie. Ponadto wartości cech, istotnych $\mathrm{w}$ ocenie niezawodności, a będących zmiennymi losowymi o określonych rozkładach prawdopodobieństwa (jak np. czasy pracy do uszkodzenia, trwania odnowy itp.), w komputerowym eksperymencie symulacyjnym można łatwo uzyskiwać poprzez wykorzystanie generatorów liczb losowych.

Przedstawiona $\mathrm{w}$ opracowaniu metoda symulacji może być $\mathrm{z}$ powodzeniem zastosowana do prognozowania trwałości kół pojazdów szynowych. W opracowanym modelu symulacyjnym widoczny jest wpływ zabiegów regeneracyjnych (odtwarzania profilu koła) na wydłużenie czasu pracy zestawów kołowych pojazdów szynowych. Możliwe jest również wykorzystanie jej do planowania i synchronizowania zabiegów regeneracyjnych poszczególnych kół funkcjonujących w zestawach kołowych.

Prace wykonano $w$ ramach Badań Statutowych prowadzonych $w$ Akademii Górniczo-Hutniczej w Krakowie na Wydziale Inżynierii Mechanicznej i Robotyki, nr 11.11.130.174.

\section{Literatura}

1. Faulin J., Juan Perez A.A., Martorell Alsina S.S., Ramirez-Marquez J.E. (red.): Simulation Methods for Reliability and Availability of Complex Systems. Springer. London 2012.

2. Fishman G.S.: Symulacja komputerowa. Pojęcia i metody. PWE. Warszawa 1981.

3. Młynarski S., Piec P.: In-service analysis of tram wheel set life. Problemy Transportu - Transport Problems, Vol. 7 (2), 2012.

4. Młynarski S., Pilch R., Smolnik M., Szybka J., Wiązania G.: A Method for rapid evaluation of k-out-of-n systems reliability. Eksploatacja i Niezawodność Maintenance and Reliability, Vol. 21 (1), 2019.

5. Młynarski S., Pilch R., Smolnik M., Szybka J., Wiązania G.: Formation of koon Systems Reliability Estimated with Analytical and Simulation Calculation Methods. Journal of KONBiN, No. 42, 2017, DOI 10.1515/jok-2017-0028. 
6. Młynarski S., Pilch R., Smolnik M., Szybka J., Wiązania G.: Methodology of network systems reliability assessment on the example of urban transport. Eksploatacja i Niezawodność - Maintenance and Reliability, Vol. 20 (2), 2018.

7. Naylor T.H.: Modelowanie cyfrowe systemów ekonomicznych. PWN. Warszawa 1975.

8. Perkowski P.: Technika symulacji cyfrowej. WNT. Warszawa 1980.

9. Piec P.: Badania eksploatacyjne elementów i zespołów pojazdów szynowych. Wyd. Politechniki Krakowskiej. Kraków 2004.

10. Pilch R.: A method for obtaining the required system reliability level by applying preventive maintenance. Simulation: Transactions of the Society for Modeling and Simulation International, Vol. 91 (7), 2015.

11. Pilch R.: Reliability evaluation of networks with imperfect and repairable links and nodes. Eksploatacja i Niezawodność - Maintenance and Reliability, Vol. 19 (1), 2017.

12. Sowa A.: Ocena stanu technicznego pojazdów szynowych na podstawie cech zdeterminowanych. Politechnika Krakowska. Kraków. 2013.

13. Sowa A.: Formal models of generating checkup sets for the technical condition evaluation of compound objects. Eksploatacja i Niezawodność - Maintenance and Reliability, Vol. 16 (1), 2014.

14. Tyszer J.: Symulacja cyfrowa. WNT. Warszawa 1990.

15. Wiązania G., Smolnik M., Pilch R.: An estimation of koon systems availability using a simulation method. Journal of Machine Construction and Maintenance, No. 4, 2017.

16. PN-EN 13715+A1: 2011: Kolejnictwo - Zestawy kołowe i wózki - Koła - Zewnętrzne zarysy wieńców kół.

17. Instrukcja pomiarów i oceny technicznej zestawów kołowych pojazdów trakcyjnych Bt-11. PKP Intercity, 2010. 